\title{
IMPROVEMENT OF THE SYSTEM OF TECHNICAL WATER SUPPLY OF THE POWER COMPLEX
}

\author{
V. Pavelko, D. Lisovyk, M. Terefenko \\ National University of Food Technologies
}

\begin{tabular}{l}
\multicolumn{1}{c}{ Key words: } \\
Modernization \\
Efficiency \\
Cooling tower \\
Heat and power plant \\
\hline \multicolumn{1}{c}{ Article history: } \\
Received 11.07.2018 \\
Received in revised form \\
27.07.2018 \\
Accepted 10.08.2018 \\
\hline
\end{tabular}

Corresponding author:

V. Pavelko

E-mail:

npnuht@ukr.net

\begin{abstract}
The paper substantiates and proves the expediency of improving the system of technical water supply of the power complex by modernizing the cooling tower to improve its operation and reduce the flow of water to it as a significant object of water consumption in the energy complex.

The design of the modernized cooling tower and separated elements of the system of technical water supply at heat and power plant is presented. The results of analytical and design studies of the reconstruction and modernization of cooling towers of the thermal power plant and the process of system of water supply are presented. The complex of measures to introduce innovative energy-saving technologies to the system of technical water supply at heat and power plant is developed and presented.

The scientific novelty of the results is to confirm experimentally the effect of reducing the flow of technological water and to improve the operation of the water cooling system in counter cooling towers. From the results of the study, it was concluded that with an increase in the thermal load of the cooling to $350 \mathrm{Gcal} / \mathrm{h}$, its cooling efficiency increases compared to the design.

It should also be emphasized that the application of the irrigation system PR-50 of the firm "Brotep-ECO" ensures a lowering of the temperature of the circulating water to 12 $13^{\circ} \mathrm{C}$, which is $3 \div 4^{\circ} \mathrm{C}$ more than the normative value for asbestos-cement irrigation. The installation of the waterabsorber BC-150 of the firm "Brotep-ECO" allows to reduce the drop loss of water to $0,001 \%$ of the total flow of circulating water to the cooling tower.

The obtained results of the performed thermal, aerodynamic and techno-economic calculations of the modernized cooling tower form the basis for introduction of engineering and technical development to improve the technological water supply system of the district heating power plant.
\end{abstract}

DOI: $10.24263 / 2225-2924-2018-24-4-19$ 


\title{
УДОСКОНАЛЕННЯ СИСТЕМИ ТЕХНІЧНОГО ВОДОПОСТАЧАННЯ ЕНЕРГЕТИЧНОГО КОМПЛЕКСУ
}

\author{
В.І. Павелко, Д.В. Лісовик, М.В. Терефенко \\ Національний університет харчових технологій
}

У статті обтрунтована і доведена доиільність удосконалення системи технічного водопостачання енергетичного комплексу шляхом модернізації градирні з метою покращчення ї̈ роботи і зменшення витрати води на неї як на значний об'єкт водоспоживання в енергокомплексі.

Приведено конструкцію модернізованої градирні баштового типу $і$ окремих елементів системи технічного водопостачання ТЕЦ. Представлено результати аналітичних $i$ проектно-конструкторських досліджень реконструкиії й модернізації градирень теплоелектростаниії та системи подачі технологічної води. Розроблений $i$ представлений комплекс заходів щзодо впровадження інноваційних енергозберігаючих технологій у системі технічного водопостачання ТЕЦ.

Наукова новизна результатів дослідження полягає в експериментальному підтвердженні ефекту зменшення витрати технологічної води та покращення роботи системи охолодження води в баштових протитечійних градирнях. 3 отриманих результатів дослідження зроблено висновок, щзо при збільшенні теплового навантаження градирні до 350 Гкал/год охолоджувальна ефективність ї̈ зростає порівняно з проектною.

Застосування зрошувача ПР-50 фірми «БРОТЕП-ЕКО» забезпечує зниження температури цчиркуляційної води до $12-13^{\circ} \mathrm{C}$, щзо на $3 \div 4^{\circ} \mathrm{C}$ більше від нормативної величини для азбесточементного зрошувача. Встановлення водоуловлювача ВС-150 фірми «БРОТЕП-ЕКО» дає змогу зменшити краплинний виніс (втрату) води до 0,001\% від загальної витрати цчиркулячійної води на градирню.

Отримані результати виконаних теплового, аеродинамічного й технікоекономічного розрахунків модернізованої градирні складають основу для впровадження інженерно-технічної розробки з удосконалення системи технологічного водопостачання теплоелектроцентралі блочного типу.

Ключові слова: модернізачія, ефективність, градирня, теплоелектроцентраль.

Постановка проблеми. Сучасні енергетичні комплекси, зокрема теплоелектроцентралі (ТЕЦ), характеризуються значним споживанням енергоносіїв у різних видах (паливо, вода, повітря), а також значним використанням водних ресурсів для технологічних потреб. Сьогодні, в умовах стрімкого підвищення цін на енергоносії, постало питання значного зменшення споживання їх у всіх галузях народного господарства, в тому числі і в енергетичних комплексах.

В енергетичній галузі досить поширеним $\epsilon$ використання в системах технічного водопостачання баштових градирень як одного з найважливіших 
елементів системи. Але у зв'язку з вичерпністю ресурсу їх роботи постає питання реконструкції (модернізації) градирень. Впровадження нових систем подачі, розпилення води, модернізація зрошувачів і водовловлювачів дасть змогу покращити процес експлуатації градирень і зменшити витрати на виробництво теплової і електричної енергії.

Мета статті: розробити комплекс заходів щодо підвищення енергоефективності теплоенергетичного обладнання ТЕЦ, зокрема системи технічного водопостачання, шляхом модернізації одного з головних елементів цієї системи - градирні.

Матеріали і методи. Нижче наводимо приклад розробленого нами варіанта удосконалення системи технічного водопостачання ТЕЦ з метою зменшення витрати води як на саму систему, так і на енергетичний комплекс в цілому.

На рис. 1а і 16 представлені схема баштової протитечійної градирні до i після модернізації, для якої були розроблені технічні рішення, запропоновані матеріали і методи щодо удосконалення ï̈ конструкції, а також передбачений комплекс заходів щодо підвищення ефективності роботи градирні в умовах експлуатації іï на ТЕЦ при різних режимах роботи.

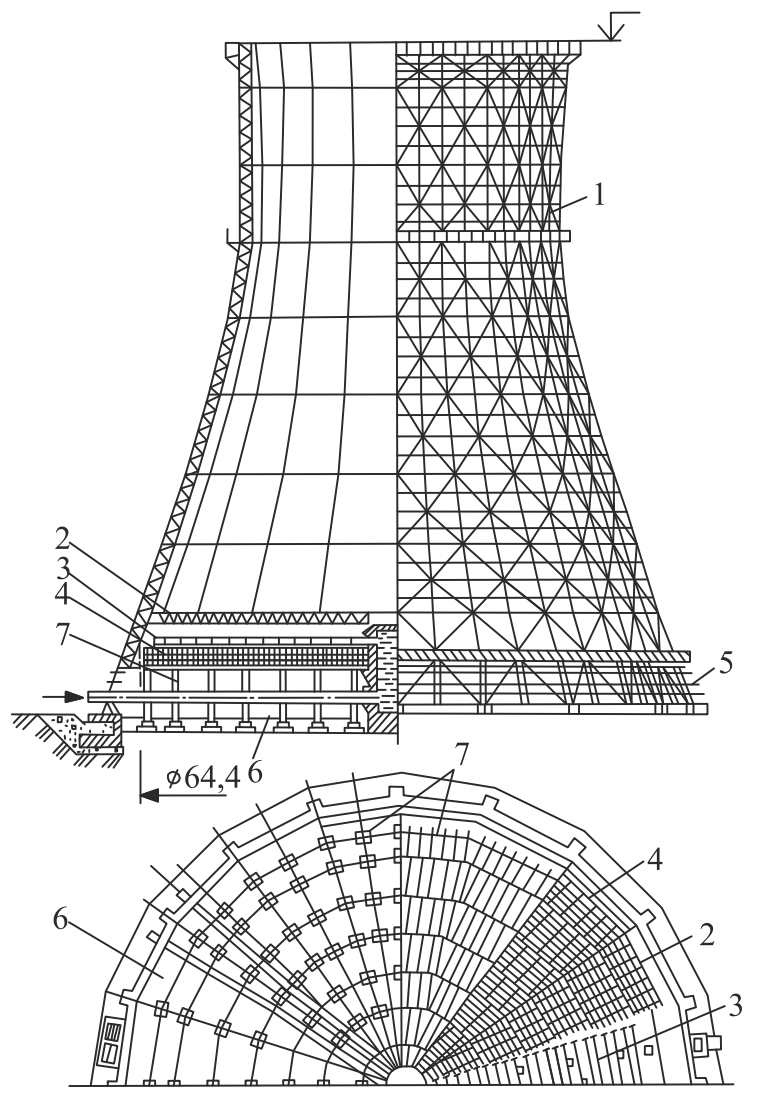

Рис. 1а. Баштова протитечійна градирня (до модернізації): 1 - витяжна башта;

2 - водоуловлювач; 3 - система водорозподілення; 4 - зрошувач;

5 - повітрорегулючий пристрій; 6 - водозбірний басейн; 7 - несучий опорний каркас 


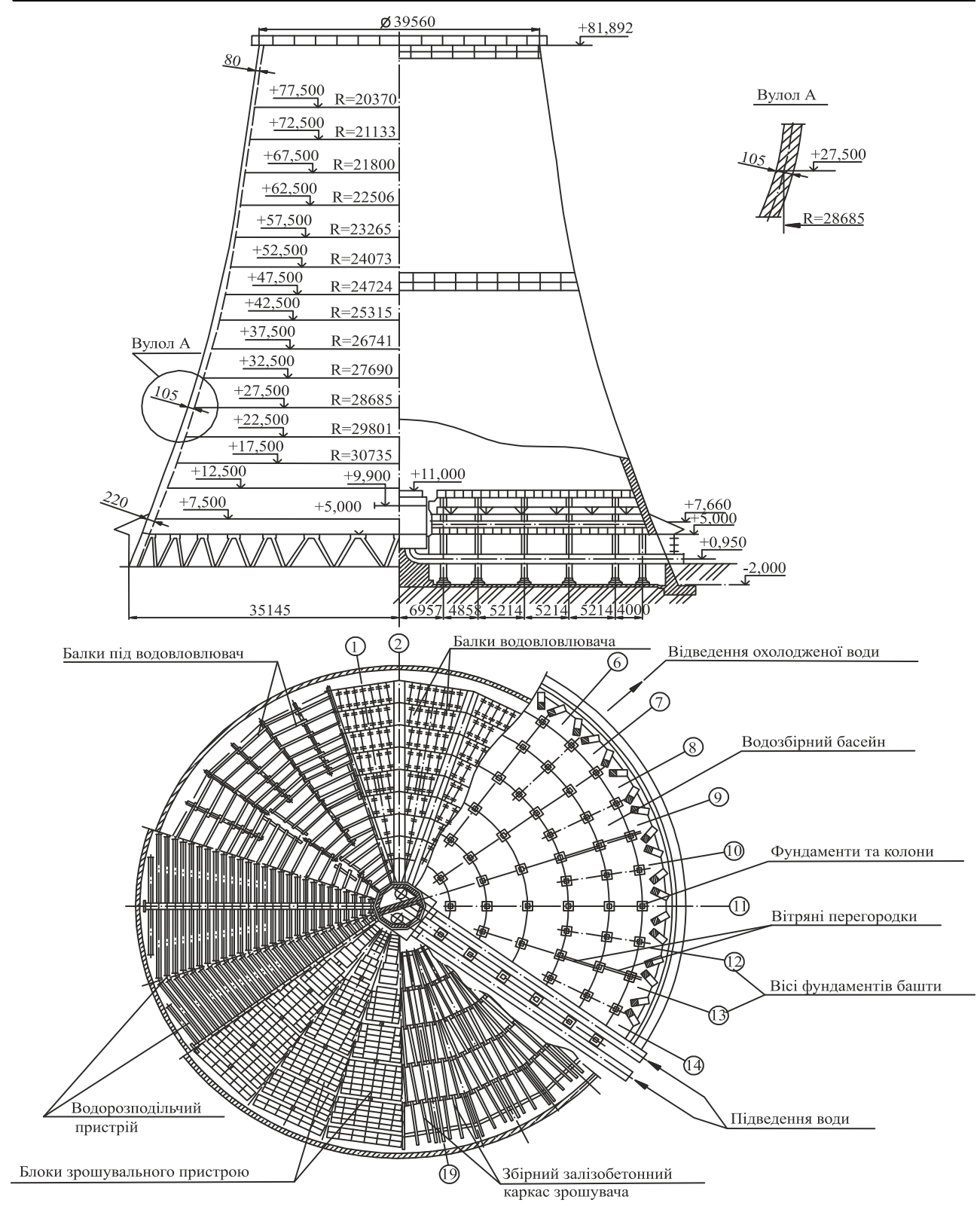

Рис. 1б. Схема модернізованої баштової протитечійної градирні

Прийняті технічні рішення щодо модернізації градирні (рис. 1):

1. Передбачити підвищення охолоджуючої ефективності градирні (зниження температури охолодженої води) понад нормативну величину, порівняно 3 градирнею з азбестоцементним зрошувачем, на $2,8-5,4^{\circ} \mathrm{C}$ залежно від величини подачі охолоджуючої води циркуляційними насосами.

2. Замінити існуючий азбестоцементний зрошувач на сучасний з полімерних матеріалів, що може забезпечити необхідну охолоджуючу ефективність градирні. 
3. Передбачити заміну робочих азбестоцементних труб системи водорозділення градирні на сталеві. Рекомендована висота установки розподільних труб над верхом зрошувача - не менше 0,5 м. Допустима швидкість води в розподільних трубах $-2 \mathrm{~m} / \mathrm{c}$.

4. Передбачити можливість зниження позначки установки системи водорозподілення градирень при умові установки зрошувача меншої висоти, ніж в існуючих градирнях.

5. Передбачити установку розбризкуючих сопел ударного типу з перфорованими відбивачами і верхнім напрямком вихідних отворів. Робочий номінальний напір води перед соплами повинен становити 1,6-1,8 м. Конструкція сопла повинна забезпечувати рівномірний розподіл води по площі зрошувача.

6. Передбачити установку кінцевих промивних сопел на робочих трубопроводах системи водорозділення, які виключать засмічення кінцевих ділянок трубопроводів і забезпечать дренаж води з низ на час зупинки градирні.

7. Передбачити заміну зруйнованого дерев'яного водо уловлювача на полімерний, який може опиратися на існуючу балочну клітку без додаткових опор. Величина краплинного виносу повинна складати не більше $0,01 \%$ від витрати води на градирню.

8. Передбачити захисне (гідрофобне) покриття внутрішньої поверхні оболонки витяжної башти градирні на рівні від початку оболонки башти до позначки установки водоуловлювача.

9. Виконати відновлення (санацію) пошкоджених ділянок оболонки витяжної башти градирні. При необхідності виконати захисне (гідрофобне) покриття внутрішньої поверхні оболонки витяжної башти.

10. Передбачити заходи проти обмерзання конструкцій водоохолоджуючого пристрою градирень:

- ремонт або заміна поворотних щитів повітронаправляючого козирка тамбуру проти обледеніння;

- установку по периметру витяжної башти на позначці верху повітровхідних вікон (під зрошувачем) кільцевого трубопроводу теплої води 3 розбризкуючими соплами та арматурою.

11. Пропускна здатність кільцевого трубопроводу повинна забезпечувати $25 \%$ номінальної витрати води на градирню.

12. Передбачити установку нахилених решіток на водовипускних головках водозбірних басейнів градирень. Виконати ремонт або заміну вітрових перегородок.

13. Передбачити подачу теплої води у водозбірний басейн градирні для його обігріву при відключенні градирні зимою. Витрата води в басейн повинна складати близько 10,0 тис. $\mathrm{M}^{3} /$ год.

Модернізація градирні (рис. 1) передбачає кілька етапів:

- відновлення будівельної конструкції градирні з усуненням усіх наявних дефектів;

- заміна азбестоцементного зрошувача на полімерний з розрахунком аеродинамічних опорів;

- відновлення гідравлічної системи зрошення;

- заміна дерев'яного водоуловлювача на полімерний; 
- розробка заходів захисту градирні в зимовий період;

- хімічна обробка води на підживлення;

3 аналізу літературних джерел [1] та проведеного аналітичного дослідження було обрано і запропоновано до установки полімерний зрошувач типу ПР-50 фірми «БРОТЕП ЕКО» [2].

Вибір зрошувача типу ПР-50 є необхідним рішенням для застосування в енергетичній, хімічній, металургійній та харчовій промисловості, де якість води низька. Він підходить для охолодження води з більш високим вмістом суспензій, мастил і високим потенціалом для збільшення об’єму виробництва.

Пакети зрошувача ПР-50 складаються 3 штампованих поліетиленових трикутних призм, з'єднаних сіткою з арматурою або термоплавкими поліетиленовими дротами для формування блоків. Конструктивні особливості трикутної призми зрошувача забезпечують рівномірний потік води та сприяють підвищенню теплової ефективності його.

Конструкція зрошувача ПР-50 і його характеристика представлені на рис. 2 і в табл. 1.
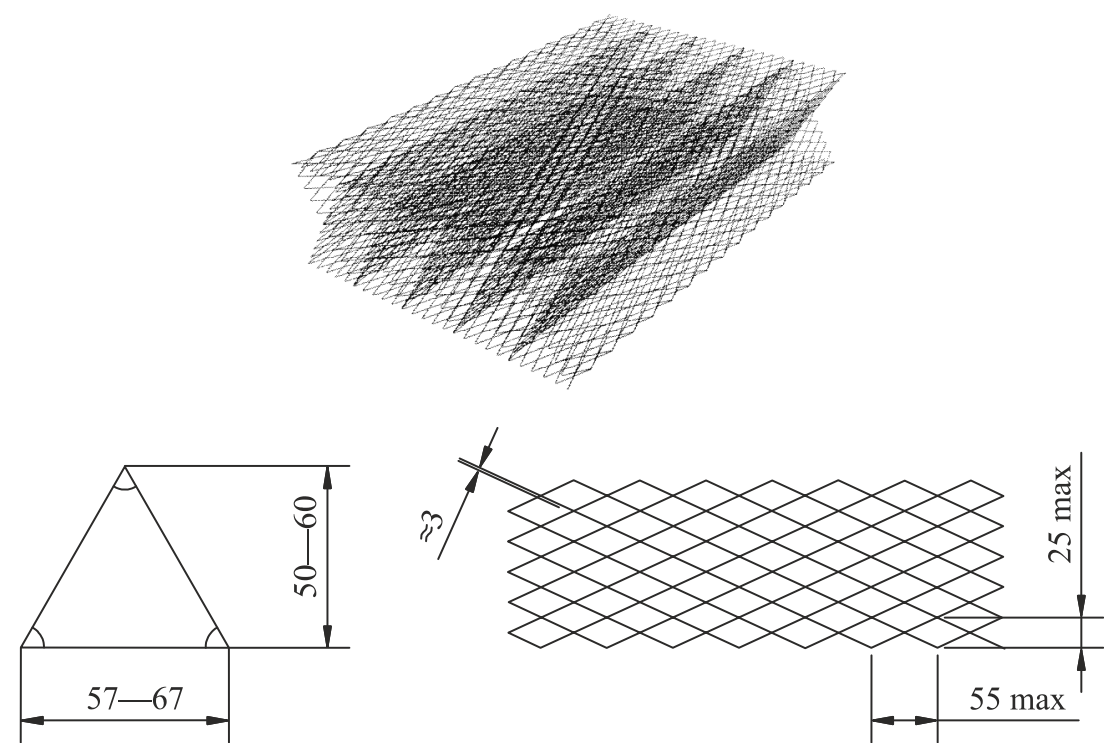

Рис. 2. Конструкція полімерного зрошувача ПР-50

Таблиия 1. Характеристика зрошувача ПР-50

\begin{tabular}{|c|c|c|}
\hline Параметр & Одиниця виміру & Величина \\
\hline Тип & & ПР-50 \\
\hline Матеріал & & ПНД \\
\hline Конкретна площа поверхні & $\mathrm{m}^{2} / \mathrm{M}^{3}$ & $60(80)$ \\
\hline Трикутна висота призми & $\mathrm{Mм}$ & 50 \\
\hline Довжина упаковки & $\mathrm{Mм}$ & $1000(1200 ; 1500 ; 2000)$ \\
\hline Ширина упаковки & $\mathrm{Mм}$ & $450(500)$ \\
\hline Висота упаковки & $\mathrm{Mм}$ & $440(50 ; 110 ; 160)$ \\
\hline Макс. температура застосування & ${ }^{\circ} \mathrm{C}$ & 80 \\
\hline Вага & $\mathrm{\kappa} \Gamma / \mathrm{M}^{3}$ & 34 \\
\hline
\end{tabular}


Запропонована модернізація повинна забезпечити покращення охолоджувальної здатності градирні. У результаті модернізації відновлюються опорна колонада, залізобетонний каркас, зовнішня поверхня вежі; замінюються зрошувач, водоуловлювач, водорозподільний пристрій градирні; змонтована система зимового обігріву.

Зрошувач градирні являє собою блоки, виготовлені з поліпропіленової фольги, які укладаються у два яруси - нижній висотою 0,6 м і верхній висотою 0,3 м. Для запобігання механічним ушкодженням фольги від ударної дії падаючих крапель води на зрошувач покладена захисна сітка хвилястого профілю. Водоуловлювач градирні запропоновано змонтувати з блоків, які збираються з профілів у вигляді на півхвилі довжиною 2400 мм і висотою фіксаторів 175 мм.

Матеріал зрошувача й водоуловлювача - поліпропілен, захищений від дії ультрафіолетових променів. Магістральні трубопроводи розподілу — зі сталевих труб Ø820×7 мм, робочі розподільчі трубопроводи - сталеві Ø194×6 мм, обладнані водорозбризкуючими соплами ударного типу 3 перфорованим відбивачем і верхнім напрямком вихідного отвору (Ø22 мм).

Для запобігання обледенінню повітровхідних вікон взимку та зменшення повітряного потоку передбачається монтаж лінії зимового обігріву, що являє собою кільцевий трубопровід Ø426×7 мм, розташований на верхній грані повітрозабірного пристрою. У кільцевому трубопроводі виконані отвори діаметром 22 мм із кроком 210-225 мм, які спрямовані таким чином, що тепла вода, яка випливає, розбризкується вниз у повітрозабірний пристрій, створюючи по периметру вежі водяну завісу. Кільцевий трубопровід розділяється на два сегменти, кожний по $180^{\circ}$, оснащені арматурою з електричним приводом.

Для промивання трубопроводу зимового обігріву на його тупикових ділянках передбачені дренажні лінії Ø100 мм із арматурою (усього 8 шт.).

На торцях трубопроводів водорозподілу передбачені зйомні заглушки для можливості промивання й очищення їх.

Результати і обговорення. В табл. 2 наведені дані щодо технічної характеристики градирні і представлені деякі результати до і після модернізації іiі за запропонованим варіантом.

Таблиия 2. Технічна характеристика градирні та деякі результати до і після їі модернізації

\begin{tabular}{|c|c|c|c|}
\hline Параметр & Од. виміру & $\begin{array}{c}\text { До } \\
\text { модернізації }\end{array}$ & $\begin{array}{c}\text { Після } \\
\text { модернізації }\end{array}$ \\
\hline 1 & 2 & 3 & 4 \\
\hline Продуктивність & $\mathrm{m}^{3} /$ год & $28 \cdot 10^{3}$ & $28 \cdot 10^{3}$ \\
\hline Густина зрошення & $\mathrm{m}^{3} /\left(\mathrm{m}^{2} \cdot\right.$ год $)$ & 8,75 & 8,75 \\
\hline Температурний перепад & ${ }^{\circ} \mathrm{C}$ & 10 & 12,5 \\
\hline Теплове навантаження & Гкал/год & 280 & 350 \\
\hline Питоме теплове навантаження & Мкал/( $\mathrm{m}^{2} \cdot$ год) & 87,5 & 109,38 \\
\hline Величина крапельного виносу & $\%$ & 0,02 & 0,01 \\
\hline
\end{tabular}




\begin{tabular}{|c|c|c|c|}
\hline \multicolumn{5}{|c|}{ Продовженн табл. 2 } \\
\hline 1 & 2 & 3 & 4 \\
\hline Глибина води у водозбірному басейні & $\mathrm{M}$ & 1,75 & 1,75 \\
\hline Висота витяжної башти & $\mathrm{M}$ & 82 & 82 \\
\hline Висота повітровхідних вікон & $\mathrm{M}$ & 5 & 5 \\
\hline Висота зрошувача & $\mathrm{M}$ & 2,5 & 0,9 \\
\hline Змочувана поверхня & тис.м ${ }^{2}$ & 440 & 460 \\
\hline Діаметр вхідних трубопроводів & мм & 1600 & 1600 \\
\hline Діаметр отвору розбризкуючи сопел & мм & 24 & 22 \\
\hline Кількість сопел & шт. & 3780 & 4251 \\
\hline
\end{tabular}

3 наведених у табл. 2 результатів можна зробити висновок, що при теплових навантаженнях градирні в межах від 200 до 350 Гкал/год охолоджувальна ефективність градирні збільшується порівняно з проектною. Застосування полімерних зрошувачів суттєво збільшує теплове навантаження градирні, збільшується термін служби зрошувача і водоуловлювача, що призводить до зменшення витрат на ремонт. Також варто зауважити, що компактні розміри зрошувача зменшують навантаження на опори, вони стають більш стійкі до зовнішніх факторів, піддаються чищенню.

Виконаний нами тепловий розрахунок для модернізованої градирні із застосуванням зрошувача ПР-50 фірми «БРОТЕП-ЕКО», який при висоті його 1 метр забезпечує зменшення температури циркуляційної води до $12,67^{\circ} \mathrm{C}$, що на $3,67^{\circ} \mathrm{C}$ більше від нормативної величини для азбестоцементного зрошувача. Втрати води при іiі охолодженні (випаровуванні) складають 2,7\% від розрахункової (проектної) витрати води на градирню. Встановлення водоуловлювача ВС-150 фірми «БРОТЕП-ЕКО» дає змогу зменшити краплинний виніс води до $0,001 \%$ від загальної витрати циркуляційної води на градирню. Для забезпечення умовно постійного хімічного стану циркуляційної води було розраховано витрату води на продувку з нижніх точок аванкамер (для видалення солей, які залишилися при випаровуванні), яка склала $0,9 \%$ від загальної витрати технічної води на градирню.

Окрім теплового, виконано аеродинамічний розрахунок для визначення аеродинамічних коефіцієнтів опору зрошувача, опору входу в градирню, опору водорозподільчого пристрою, опору водоуловлювача, опору дощу, загального опору, повного аеродинамічного опору градирні, а також сили тяги в ній. На підставі аеродинамічного розрахунку була отримана кількісна характеристика витрати повітря, яке проходить через градирню та його відносну витрату.

Метою проведення техніко-економічного розрахунку було визначення доцільності модернізації градирні. Так, за іiі результатами можна зробити висновок, що розрахований чистий приведений дохід - величина позитивна і складає 30,04 млн грн. Це означає, що віддача від модернізації градирні на 30,04 млн грн перевищує перекриття інвестиційних вкладень, що становлять 3 урахуванням податку на додану вартість 126,53 млн грн.

Індекс дохідності складає 1,24. Це означає, що віддача від впровадження проекту модернізації в 1,24 раза перевищує інвестиційні вкладання. Інакше кажучи, з однієї гривні вкладань передбачається отримувати 1,24 гривні віддачі. 
Реальний (дисконтований) період повернення інвестицій знаходиться в межах життєвого циклу проекту і складає 4,04 року.

Порівняння розрахованих показників 3 нормативними значеннями та їx аналіз дає змогу зробити висновок про доцільність модернізації градирні за запропонованим нами варіантом.

\section{Висновки}

1. Запропонований варіант модернізації градирні ТЕЦ суттєво підвищує енергоефективність цього основного елемента системи технічного водопостачання.

2. Практичне значення отриманих результатів дослідження роботи модернізованої градирні полягає у можливості впровадження цього проекту в системах технічного водопостачання теплових електростанцій блочного типу.

\section{Лiтература}

1. Пономаренко В.C. О реконструкции вентиляторных градирен // Химическая промышленность. Москва : - 1996. - № 7. - С. 45-52.

2. Пономаренко В.С. Градирни промышленных и енергетических предприятий / В.С. Пономаренко, Ю.И. Арефьев // Справочное пособие. Москва : Энергоатомиздат. - 1998. 248c.

3. Расчеты вентиляторных градирен. Методические указания для курсового и дипломного проектирования для студентов специальности 144 «Теплоэнергетика» всех форм обучения / А.Р. Переселков, О.В. Круглякова. - Харьков : НТУ «ХПИ». - 2016. - 56 с.

4. Арефьев Ю.И. Пластмассовые водоуловители градирен / Ю.И. Арефьев, В.С. Пономаренко // Водоснабжение и санитарная техника. — 2004. — № 10. - С. 8 - 15 .

5. Технические указания по расчету и проектированию башенных противоточных градирен для тепловых электростанций и промышленных предприятий / СНиП $14-67$ Минэнерго СССР. - Москва :«Энергия», 1991. — 58 с. 